\title{
シリカーアルミナセラミックスの機械的性質に及ぼす 化学組成の影響
}

\author{
熊沢＼cjkstart猛・神 崎修三* ·太田滋俊・田端英世* \\ ( 美濃窯業 (株) 技術研究所, 475 半田市龟崎北浦町 1-46 $)$ \\ *名古屋工業技術試験所, 462 名古屋市北区平手町 $1-1)$
}

\section{Influence of Chemical Composition on the Mechanical Properties of $\mathrm{SiO}_{2}-\mathrm{Al}_{2} \mathrm{O}_{3}$ Cera mics}

\author{
Takeshi KUMAZAWA, Shuzo KANZAKI*, Shigetoshi OHTA and Hideyo TABATA \\ $\left(\begin{array}{c}\text { Technical Research Laboratory, Mino Yogyo Co., Ltd., Kamezaki Kitaura-cho, Handa-shi } \\ \text { * Government Industrial Research Institute, Nagoya, 1-1, Hirate-cho, Kita-ku, Nagoya-shi } 462\end{array}\right)$
}

\begin{abstract}
Mechanical properties of $\mathrm{SiO}_{2}-\mathrm{Al}_{2} \mathrm{O}_{3}$ ceramics were studied in relation to the chemical composition. Raw powders of the composition ranging from 60 to $78 \mathrm{wt} \% \mathrm{Al}_{2} \mathrm{O}_{3}$ were synthesized by the spray pyrolysis method and sintered at $1650^{\circ} \mathrm{C}$ for $4 \mathrm{~h}$. The room temperature flexural strength and fracture toughness of the specimens showed no significant difference with the composition ranging from 66 to $78 \mathrm{wt} \% \mathrm{Al}_{2} \mathrm{O}_{3}$. But for the $\mathrm{SiO}_{2}$-rich specimens containing less than 66 wt\% $\mathrm{Al}_{2} \mathrm{O}_{3}$, those values decreased slightly. For the $\mathrm{Al}_{2} \mathrm{O}_{3}$-rich specimens which contain no glassy phase, the high-temperature strength and fracture toughness decreased gradually with increasing temperature. In contrast, the strength and the $K_{I C}$ of the specimens containing both mullite and a glassy phases increased with increasing silica content and increasing temperature up to $1300^{\circ} \mathrm{C}$. While the flexural strength decreased drastically at $1400^{\circ} \mathrm{C}$. The maximum fracture strength at high temperature depends on both chemical composition and the amount of grain boundary glassy phase. The increase in strength and fracture toughness for the $\mathrm{SiO}_{2}$-rich specimens at high temperatures is explained in terms of stress relaxation and/or crack healing in the grain boundary glassy phase, and pull out of acicular mullite grains due to decrease in viscosity of the glassy phase, respectively.
\end{abstract}

[Received August 10, 1987 ; Accepted September 17, 1987]

Key-words : $\mathrm{SiO}_{2}-\mathrm{Al}_{2} \mathrm{O}_{3}$ ceramics, Mullite, Flexural strength, Fracture toughness, Glassy phase, Stress relaxation, Crack healing

\section{1. 緒 言}

ムライト $\left(3 \mathrm{Al}_{2} \mathrm{O}_{3} \cdot 2 \mathrm{SiO}_{2}\right)$ で代表されるシリカーア

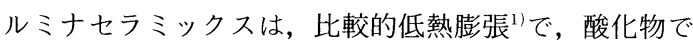

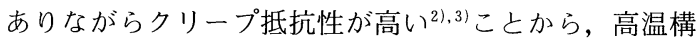
造材料への応用が期待されている材料の一つとなってき た。しかしながら高温におけるムライトセラミックスの 機械的性質についての報告は，比較的少ない．Mah ら は，アルコキシド法によるムライトセラミックスの高温 特性について検討し, 高温における破壊鞁性值の上昇は, 粒界に存在するガラス相の影響であると述べている。し かし, 彼らの結果は, 強度の絶対值が室温で約 200 $\mathrm{MPa}$ と必ずしも高くはない.

一方，著者らは，噴霧熱分解法による合成粉末を用い ると, 高純度で高密度のムライトセラミックスが作製で きること, 更に化学量論組成の試料で室温から $1300^{\circ} \mathrm{C}$ まで約 $380 \mathrm{MPa}$ と今まで報告されたムライトセラミッ クスに比較して高い強度を示すことを既に報告")した。 また化学組成により,特に高温での機械的特性が変化し, 高温でわずかにシリカに富む組成で高い強度が得られる

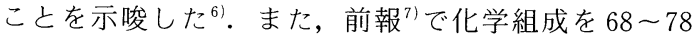
$\mathrm{wt} \% \mathrm{Al}_{2} \mathrm{O}_{3}$ の範囲で変化させた場合のシリカーアルミナ セラミックスの焼結性と微構造との関係について検討 し，組成と微構造に大きな相関があることを述べた.

そこで本研究では，アルミナ含有量 60〜 78 wt\% の粉 末を噴霧熱分解法で合成し，シリカーアルミナセラミッ クスの化学組成と微構造及び機械的特性の関係について 更に詳細な検討を行った。

\section{2. 実験方法}

実験に用いた原料粉末は，アルミナ含有量が 60 から $78 \mathrm{wt} \%$ となるように，前報 ${ }^{7}$ で述べた噴霧熱分解法に より合成し， $950^{\circ} \mathrm{C}, 1$ 時間仮焼してムライト化し，粉 砕処理を行って調製した.これらの粉末を金型にて予備 成形した後, $200 \mathrm{MPa}$ で静水圧成形した。焼成は，大 気中 $10^{\circ} \mathrm{C} / \mathrm{min}$ の速度で昇温し, $1650^{\circ} \mathrm{C}$ で 4 時間保持 して行い，約 $40 \times 30 \times 5 \mathrm{~mm}$ の焼結体を作製した，得ら れた焼結体から直方体形状の試片を切り出し，各面を \#400のダイヤモンド砥石で研削加工後, エッジを丸め, 
最終的に JISR 1601 形状の $3 \times 4 \times 36 \mathrm{~mm}$ の抗折強度試 験片を作製した。また，破壊靫性 $K_{\mathrm{IC}}$ 測定用試験片は， 抗折強度試験の $4 \mathrm{~mm}$ 方向を厚さ方向とし, 試料の中央 にダイヤモンドブレードで深さ $1 \mathrm{~mm}$, 幅 $0.1 \mathrm{~mm}$ のノッ チを導入し作製した，強度試験は，3点曲げ法による室 温から $1400^{\circ} \mathrm{C}$ の温度範囲で行い, クロスヘッド速度 $0.5 \mathrm{~mm} / \mathrm{min}$ で各点 3 本以上測定した。 また, 破壊勒性 $K_{\text {IC }}$ は, Single Edge Notched Beam 法で, 上部スパン $10 \mathrm{~mm}$ 下部スパン $30 \mathrm{~mm}$ の 4 点曲げにより,クロスヘッ ド速度 $0.05 \mathrm{~mm} / \mathrm{min} て ゙$ 行い, Brown ら ${ }^{81}$ の式により算 出した。抗折強度，破壊䩲性の測定は，いずれも島津製 作所製オートグラフ DCS-2000にて大気中で行った。

Table 1. Composition, bulk density and crystal phase of the specimens (sintered at $1650^{\circ} \mathrm{C}$ for $4 \mathrm{~h}$ ).

\begin{tabular}{c|c|c|c} 
Symbol & $\begin{array}{r}\mathrm{Al}_{2} \mathrm{O}_{3} \text { content } \\
(\mathrm{wt} \%)\end{array}$ & $\begin{array}{r}\text { Bulk density } \\
(\mathrm{g} / \mathrm{ml})\end{array}$ & Crystal phase \\
\hline $60 \mathrm{~A}$ & 60.0 & 2.94 & $\mathrm{M}, \mathrm{G}$ \\
$64 \mathrm{~A}$ & 64.1 & 3.01 & $\mathrm{M}, \mathrm{G}$ \\
$66 \mathrm{~A}$ & 65.8 & 3.04 & $\mathrm{M}, \mathrm{G}$ \\
$68 \mathrm{~A}$ & 67.8 & 3.07 & M,G \\
$70 \mathrm{~A}$ & 70.3 & 3.05 & M, G \\
$71.8 \mathrm{~A}$ & 72.1 & 3.02 & M,G \\
$74 \mathrm{~A}$ & 74.3 & 3.05 & M \\
75A & 74.9 & 3.01 & M,C \\
78A & 77.8 & 3.08 & M,C
\end{tabular}

更に, 試料中のクラックの進展状態は, 試料を研磨後熱 エッチングした面に，ビッカース硬度計（明石製作所， $\mathrm{AV}$ - II 型）にて圧子を $10 \mathrm{~kg}$ の荷重で導入し，生じたク ラックを走査型電子顕微鏡にて観察した。また，試験片 の微構造観察は，破断面及び研磨後の熱エッチング $\left(1500^{\circ} \mathrm{C} ， 20\right.$ 分処理) 面，化学エッチング (HF $1 \%$ 溶液中; $0^{\circ} \mathrm{C}, 24$ 時間処理）面について，走査型電子顕 微鏡（日本電子製，T 300）により行った。更に，粉末 X 線回折装置（理学電機製，Rad-Ru）を用い，結晶相 を同定した。

\section{3. 実験結果と考察}

\section{1 抗折強度に及ぼす組成の影響}

用いた試料の特性を表 1 に,また, 代表的な微構造 (熱 エッチング面）を図１に示す．試料名は，それぞれのア ルミナ含有量を表し，例えば $68 \mathrm{~A}$ は，アルミナ含有量 $68 \mathrm{wt} \%$ を示している. 試料のかさ密度及び, 研磨面の 走査型電子顕微鏡観察結果から $71.8 \mathrm{~A}$ よりシリカ過剩 側の組成では，ほぼ完全にち密化しているに対し，71.8 A よりアルミナ過剩側で 2 3\%の気孔が認められた。 また，各試料の研磨，エッチング面の電子顕微鏡観察， 及び粉末 X 線回折結果から，74 A 組成のみムライト単 一相であり等軸状の粒子形状を示すのに対し，この組成 よりシリカ過剩側では，柱状に成長したムライト粒子と ガラス相，アルミナ過剰側では等軸状のムライト粒子と コランダムからそれぞれなることが分かった。
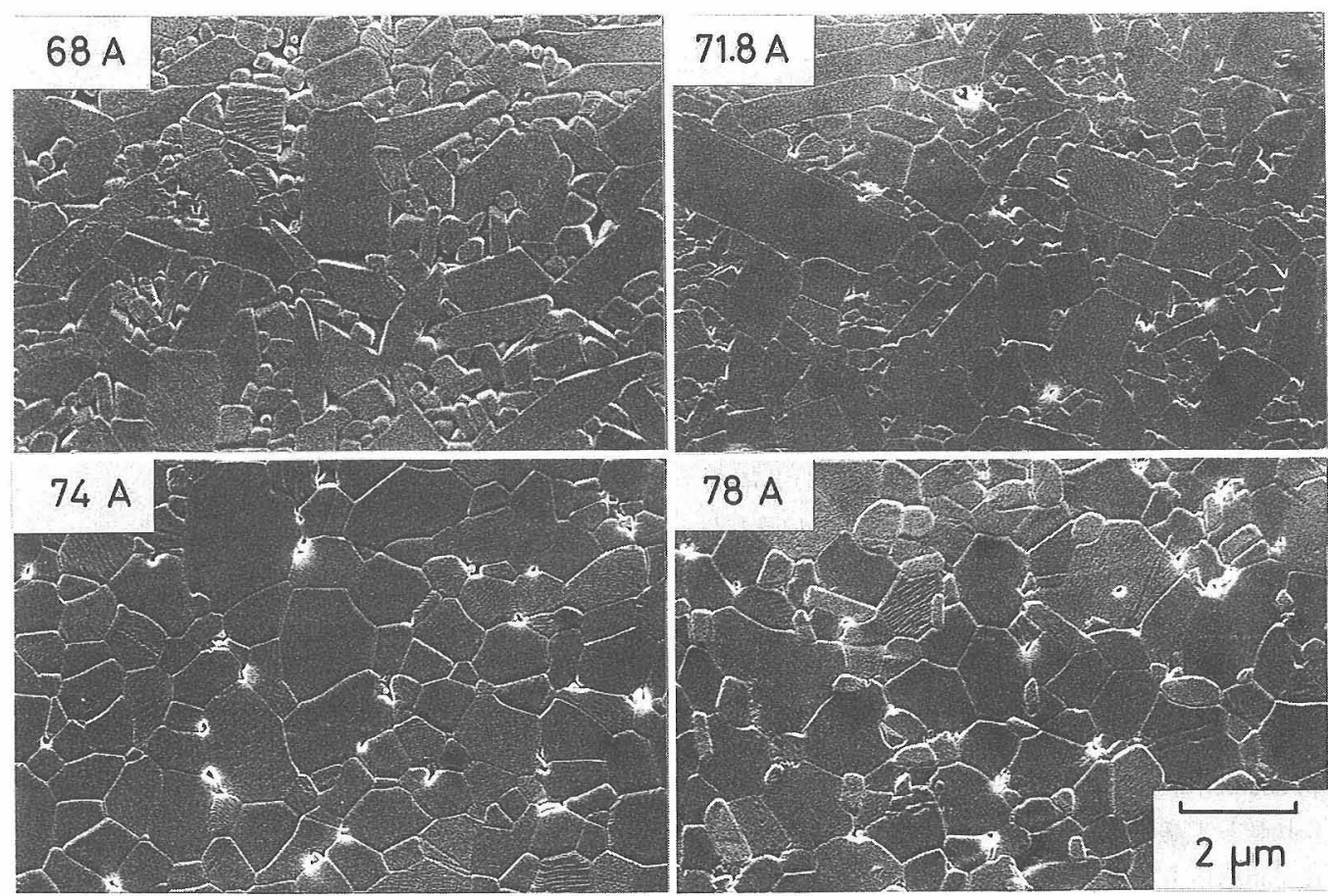

Fig. 1. Scanning electron micrographs of polished thermal etched surface of the specimens. 


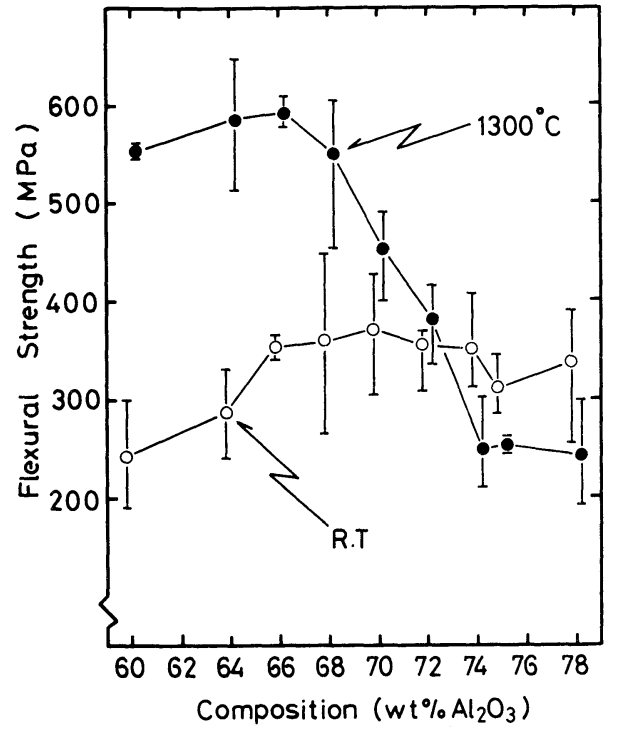

Fig. 2. Flexural strength of the specimens at room temperature and at $1300^{\circ} \mathrm{C}$ in air vs. chemical composition.

$60 \mathrm{~A}$ から $78 \mathrm{~A}$ の組成範囲における各試料の室温及び $1300^{\circ} \mathrm{C}$ でのアルミナ含有量と抗折強度の関係を図 2 に 示す. $66 \mathrm{~A}$ から $78 \mathrm{~A}$ の組成領域での室温強度は, いず れも約 $350 \mathrm{MPa}$ とほぼ同じ值であるのに対して，64 A よりシリカ過剩組成では, シリカ含有量の増加とともに 室温強度は低下する傾向を示した.

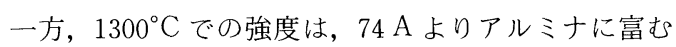
組成では室温強度より低くなるのに対して，74 A より シリカに富む組成ではシリカ含有量の増加に伴い，66 $\mathrm{A}$ まで直線的に強度が高くなる傾向にあり，66 A で室 温強度の約 1.4 倍の $590 \mathrm{MPa}$ を示した. しかし, 更に シリカ含有量が高くなると, 室温強度と同様に高温強度 は低下する傾向にはあるが， $60 \mathrm{~A}$ 組成で $550 \mathrm{MPa}$ と室 温の約 2 倍を示す.

このように, 組成により室温, $1300^{\circ} \mathrm{C}$ での強度の傾 向が異なるため, 次に, $60 \mathrm{~A}, 68 \mathrm{~A}, 71.8 \mathrm{~A}, 74 \mathrm{~A}$ 試料 について室温から $1400^{\circ} \mathrm{C}$ までの温度範囲での抗折強度 の変化を調べた. 図3にその結果を示す.ムライト単一 相である $74 \mathrm{~A}$ は，温度の上昇によりゆるやかに強度が 低下するのに対して，ムライトとガラス相の共存する $71.8 \mathrm{~A}$ よりシリカ過剩組成では, いずれも $1300^{\circ} \mathrm{C}$ まで 強度は温度とともに増加する傾向を示す. 特に $60 \mathrm{~A}$, $68 \mathrm{~A}$ では $1200^{\circ} \mathrm{C}$ から $1300^{\circ} \mathrm{C}$ にかけて急激な強度上昇 が認められた。また，ガラス相の存在する組成では，い ずれも $1400^{\circ} \mathrm{C}$ で著しく強度が低下し，その低下の割合 は, シリカ含有量が高いほど高くなっている，これらの 結果から，シリカーアルミナセラミックスの抗折強度に 及ぼす組成の影響は，ムライト単一相である $74 \mathrm{~A}$ 組成

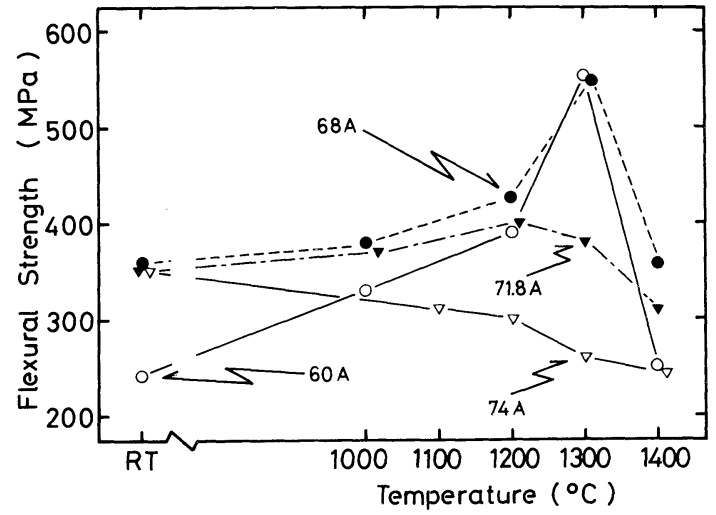

Fig. 3. Temperature and chemical composition dependence of the flexural strength of the specimens.

を含むアルミナ過剩側のガラス相を含まない組成とガラ ス相を含む組成でそれぞれ異なることが分かる.

まずガラス相を含まない組成について考えると，この 組成域での抗折強度は温度が高くなるにつれ低下する傾 向にある. 一般に, 七ラミックスの強度 $\sigma$ は, Griffith のぜい性破壊理論9'より

$$
\sigma=(2 r E / \pi a)^{1 / 2}
$$

で示され, 内部き裂 $a$ や破壊エネルギー $r$ が一定とす ると, 強度は弾性率に比例するといえる。 またセラミッ クスの高温での性質として, Soga ${ }^{101}$ は多くの場合, セラミックスの弾性率は温度とともに低下する傾向を示 すことを報告している. 更に $74 \mathrm{~A}$ の弾性率 ${ }^{11}$ は, 室温 で $205 \mathrm{GPa} ， 1300^{\circ} \mathrm{C}$ で $180 \mathrm{GPa}$ と温度の上昇に伴って 低下することから，ガラス相を含まない組成での抗折強 度は，高温で低下すると考えられる，一方，ガラス相を 含む組成での抗折強度は温度によって大きく変化してお り, 組成によって変化する度合は異なるが，いずれもあ る温度までは温度の上昇とともに高くなる傾向を示して いる.

ガラス相の存在する組成で生成するガラス相の量は組 成により異なり，そのため高温での破壊挙動が異なると 考えられる。そこで代表的な例として，60A と68 A に ついて比較検討した。図 4 に $60 \mathrm{~A}$ と $68 \mathrm{~A}$ の熱エッチ ング及び, 化学エッチング面の観察結果を示す.なお, エッチングを施さない研磨面の観察よりいずれも気孔

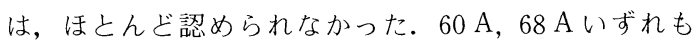
ムライト粒子の大きさ, 形状は, ほぼ同じであるが，化 学エッチングにより生じた穴からガラス相の分布状態は $68 \mathrm{~A}$ では粒界の 3 重点付近にのみ存在していることが

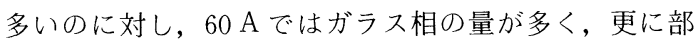
分的に連続して存在していたことが認められる. $60 \mathrm{~A}$, $68 \mathrm{~A}$ の各温度での抗折強度測定時に得られる応力と変 位の関係を図 5 , 及び図 6 にそれぞれ示す.いずれも $1200^{\circ} \mathrm{C}$ 以下では，ぜい性破壊を示しているが， $60 \mathrm{~A}$ は， 

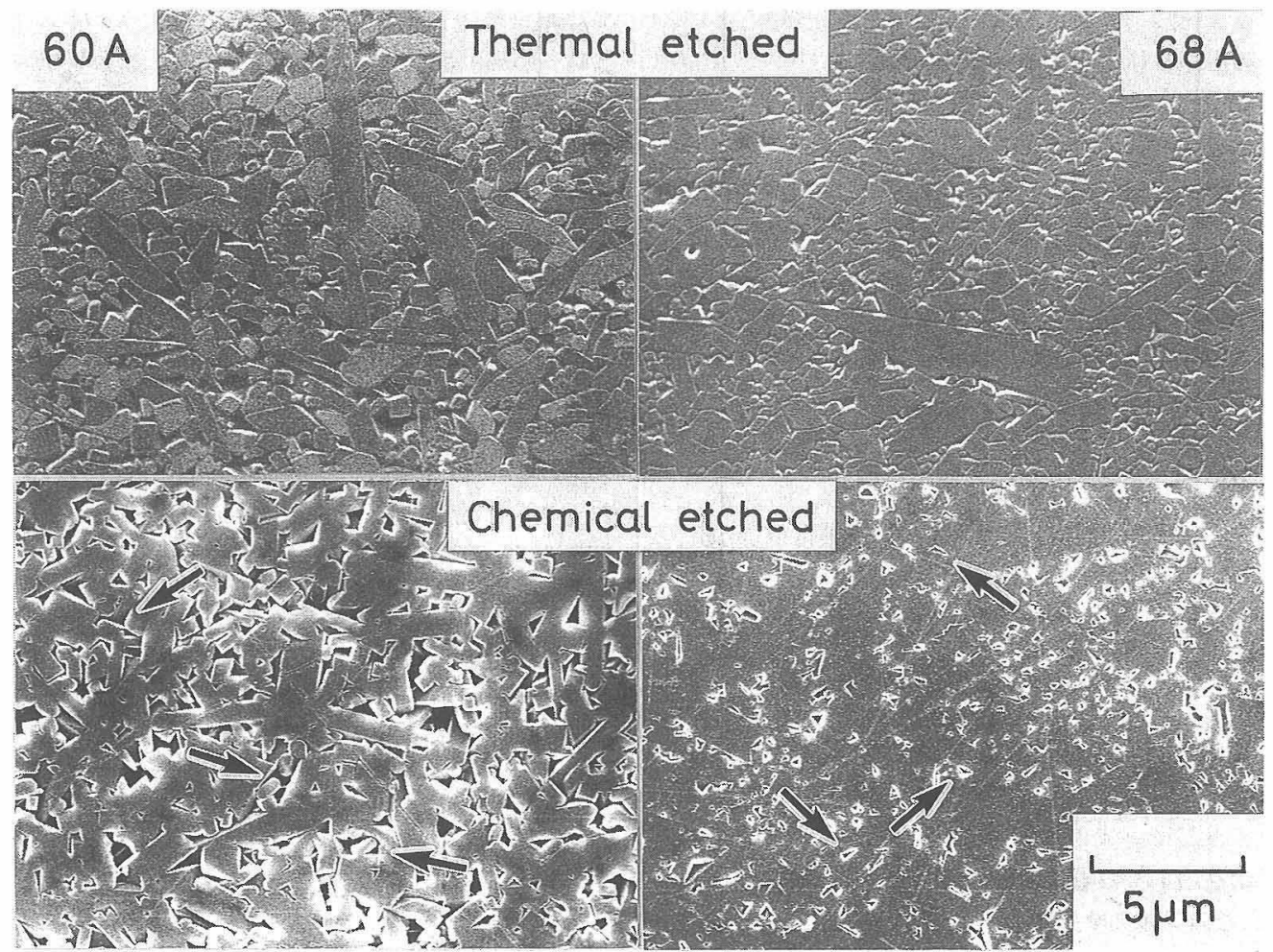

Fig. 4. Scanning electron micrographs of $60 \mathrm{~A}$ and $68 \mathrm{~A}$ specimens.

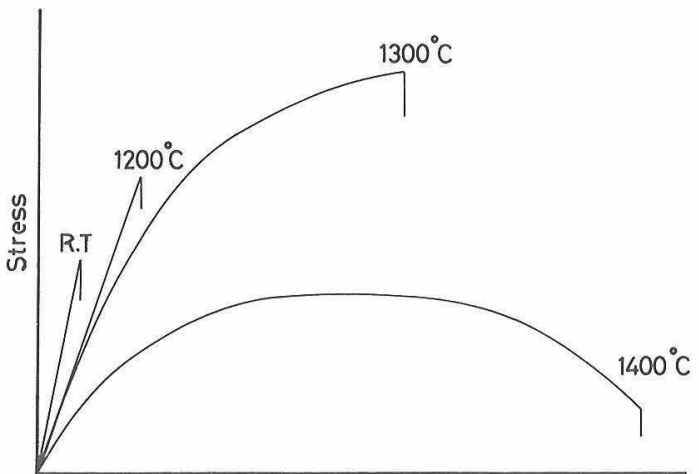

Deflection

Fig. 5. Typical stress-deflection curves for $60 \mathrm{~A}$ specimen.

$1300^{\circ} \mathrm{C}$ でかなりの塑性变形を伴って破壊し， $1400^{\circ} \mathrm{C} て ゙$ は更に変形量が大きくなっている。それに対して，68 $\mathrm{A}$ では $1300^{\circ} \mathrm{C}$ でわずかに塑性変形が認られ， $1400^{\circ} \mathrm{C}$ でも変位量は $60 \mathrm{~A}$ の $1 / 3$ であった。このようにガラス 相の存在する組成において, 見掛けの強度がほぼ同じで あっても, ガラス相の存在する量により, 高温での破壊 挙動はことなっていることが分かる。つまり，Mahら が指摘している4)ように，ガラス相の存在によりシリカ ーアルミナセラミックスは, ガラス相中での応力緩和や クラック先端の鈍化により高温で抗折強度の上昇が認め

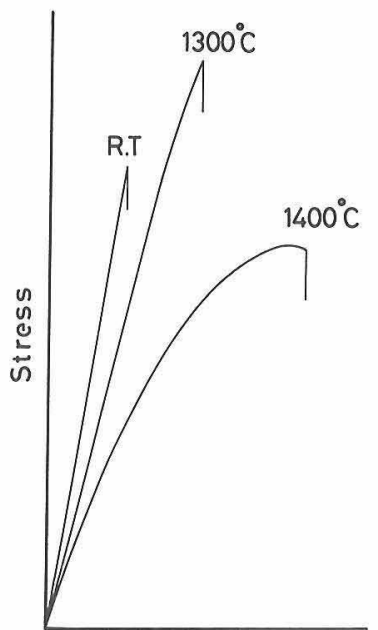

\section{Deflection}

Fig. 6. Typical stress-deflection curves for $68 \mathrm{~A}$ specimen.

られる.しかしながら，高温での抗折強度の上昇は，ガ ラス相の分布状態により異なりガラス相が少なくムライ 卜粒子の三重点付近にのみ存在する場合には，ガラス相 中での応力緩和やクラック先端の鈍化の影響が顕著にな るのに対し，ガラス相の量が多くムライト粒界にガラス 相が連続して存在すると，比較的低温からガラスの塑性 


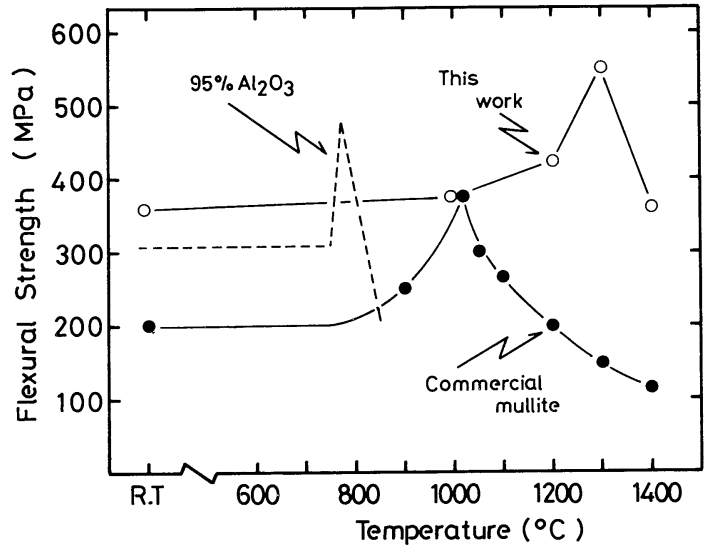

Fig. 7. Temperature dependence of the flexural strength of $68 \mathrm{~A}$, commercial mullite and alumina (92 wt $\% \mathrm{Al}_{2} \mathrm{O}_{3}$ ).

変形が支配的になり，低温からの強度の上昇が説明でき る.

一方, ガラス相を含む場合の高温強度は, ガラス相の 分布状態とともにガラスの組成, 純度にも影響されると 考えられる. しかしながら, 高温強度に及ぼすガラス相 の組成や量の影響についての検討は比較的少ない212),13).

図 7 に市販のムライト ${ }^{14)}\left(67 \mathrm{wt} \% \mathrm{Al}_{2} \mathrm{O}_{3}\right.$ 組成）及びア ルミナ ${ }^{15)}$ と本試料の $68 \mathrm{~A}$ について比較した結果を示 す.このアルミナ試料中には多くのガラス相が存在しガ ラ又相の化学組成は, $35.3 \% \mathrm{Al}_{2} \mathrm{O}_{3}, 33.5 \% \mathrm{SiO}_{2}$, $27.0 \% \mathrm{CaO}, 4.1 \% \mathrm{Na}_{2} \mathrm{O}$ であると報告 ${ }^{15)}$ している. ま た,市販のムライトについては, 天然のアルミノシリケー 卜を原料を用いたものであり, 不純物が比較的多いと述 べられている ${ }^{14)}$. 室温で $68 \mathrm{~A}$ と強度がほぼ同じである アルミナは, $730^{\circ} \mathrm{C}$ 付近から強度の上昇が見られ, $770^{\circ} \mathrm{C}$ で最大となりその後急激に低下するのに対し, 68 $\mathrm{A}$ では, $1300^{\circ} \mathrm{C}$ で強度は最大ピークを示す。また市販 のムライトは $68 \mathrm{~A}$ とほぼ同じアルミナ含有量であるに もかかわらず, $1000^{\circ} \mathrm{C}$ 付近で強度の最大ピークを示し ている. 前述したように粒界にガラス相が存在すると温 度の上昇に伴い粘性が低下 ${ }^{16}$ し応力緩和やクラック先端 の鈍化により即時破壊強度は増加するが, 更に粘性が低 下する高温では粒界相が容易に塑性変形するため強度が

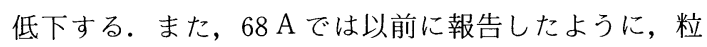
界に存在するガラス相は, ほぼ純粋なシリカガラスであ るのに対し, アルミナ試料では, 粒界ガラス相中に多量 の $\mathrm{Na}_{2} \mathrm{O}, \mathrm{CaO}$ を含んでおり ${ }^{15)}$ ，また市販のムライト試 料では, 出発原料である天然アルミノシリケートに多く 不純物が存在している ${ }^{14)}$. このように粒界ガラス相の組 成が異なるため, 本実験のムライトと比較した場合, 強 度の最大ピークを示す温度が, 不純物の多い試料では, 低温にシフトしたと考えられる，しかしながら，本報告

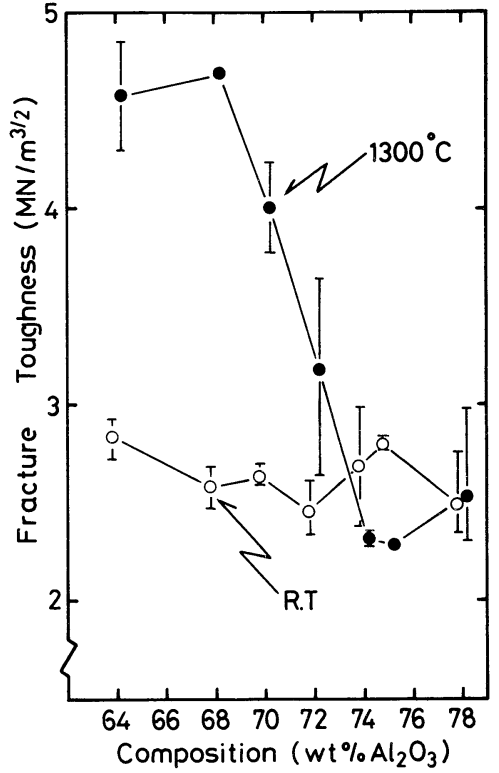

Fig. 8. Fracture toughness of the specimens at room temperature and at $1300^{\circ} \mathrm{C}$ vs. chemical composition.

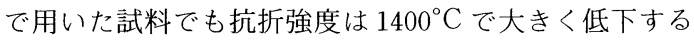
傾向を示したが，これは不純物として粉末中に，例えば $\mathrm{Na}_{2} \mathrm{O}$ が約 $240 \mathrm{ppm}$ 含まれている7ためと思われる.

\section{2 破壊靫性 $K_{\mathrm{IC}}$ に及ぼす組成の影響}

図 8 に $64 \mathrm{~A}$ から $78 \mathrm{~A}$ の組成範囲における, 室温, $1300^{\circ} \mathrm{C}$ での組成による破壊鞁性值の変化を示す. 室温

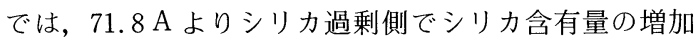

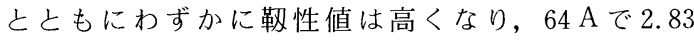

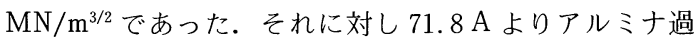
剰側では，いずれも 71.8 A と同じかわずかに高い值を 示した。一方 $1300^{\circ} \mathrm{C}$ での破壊䩲性值は, $74 \mathrm{~A}$ 以上のア ルミナ過剩組成でいずれも室温より低いにの対し, 74 $\mathrm{A}$ よりシリカ過剩側ではシリカ含有量の増加と共に靱 性值は増大し, $68 \mathrm{~A}$ で最大 $4.70 \mathrm{MN} / \mathrm{m}^{3 / 2}$ を示した。こ の破壊䩲性值の組成による変化は, 図 2 に示した抗折強 度の変化とほぼ同様な傾向を示している。 つまり，ガラ 又相の存在する組成では，いずれの組成においても室温 より $1300^{\circ} \mathrm{C}$ で勒性值は高く, 室温及び $1300^{\circ} \mathrm{C}$ でガラ ス含有量の増加にともなって高くなる傾向を示してい る.一般に, 複合体の室温での機械的特性は, 内部応力 の増加により高くなることが知られている. Shinkai $ら^{18)}$ は高ひずみ領域を有する分相ガラスについての室 温での勒性值は, ひずみ領域の増加により高くなり, こ れはひずみにより発生するマイクロクラックで主き裂が 遮へいされるためであると報告している，また，図6に 示したように，シリカ含有量が増加すると，ガラス相は 部分的に連続する領域が認められた。ここでガラス相を 含む組成は，一種の複合材料と考えると室温での組成に 

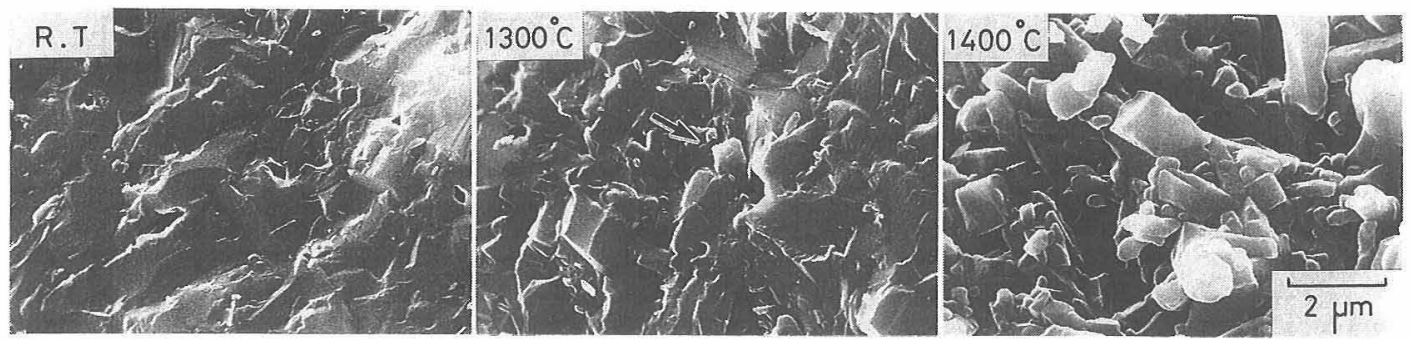

Fig. 9. Scanning electron micrographs of fracture surface of $68 \mathrm{~A}$ specimen.

よる勒性值の変化の傾向は，ムライトとガラス相の熱膨 張係数 ${ }^{1)}$ の差 (シリカガラス $0.5 \times 10^{-6} /{ }^{\circ} \mathrm{C}$ ，ムライト $\left.5.3 \times 10^{-6} /{ }^{\circ} \mathrm{C}\right)$ により生じる残留ひずみの領域が，シリ 力含有量の增加により広くなるため見掛け上靶性值が高 くなったと思われる。一方，ガラス相を含む組成の高温 での鞀性值は，3.1節で述べたように粒界に存在するガ ラス相の影響が著しいと考えられる，図 9 に，温度によ り抗折強度が顕著に変化した $68 \mathrm{~A}$ の各温度での破面観 察結果を示す．室温から $1200^{\circ} \mathrm{C}$ までの破面は，比較的 平たんであるのに対し，抗折強度が大きく上昇した $1300^{\circ} \mathrm{C}$ では，全体に凹凸のある破面となり，部分的に 粒子の引き拔かれた形跡が認められた。更に高温である $1400^{\circ} \mathrm{C}$ では，粒子の引き抜きが顕著に生じて破断して いる. Evans ら ${ }^{199}$ は，マトリックス中にウイスカーを分 散した系で, ウイスカーの引き抜きにより，クラック先 端に近い部分においてクラック上下面をウイスカーがブ リッジすることで，クラック先端の応力集中を著しく低 下させることから高䩚化が可能であると説明している. このように，ガラス相を含む組成での $1300^{\circ} \mathrm{C}$ の鞁性值 は，前述したように粒界に存在するガラス相中での応力 緩和やクラックの先端の鈍化，更に高温でのガラス相の 軟化に伴う部分的な柱状のムライト粒子の引き抜きによ り，室温の䩲性值と比較して高くなり，またガラス相の 存在割合の増加とともに空温に対する $1300^{\circ} \mathrm{C}$ の靶性値 の比は，大きくなるといえる.

それに対してガラス相の存在しない組成，特にコラン ダムが共存する組成では，第 2 相成分であるコランダム によりクラックが偏向 ${ }^{201}$ L，破壊䩲性值は，他の組成よ り高くなると予想したが, $71.8 \mathrm{~A}$ とほぼ同値であった。 図 10 に, $78 \mathrm{~A}$ の研磨面にビッカース圧子を導入した際 に発生したクラックの状態を観察した結果を示す。ク ラックは，コランダムの粒界にそって偏向するが，ムラ イトの粒内を容易に通過していることから，この場合の 第 2 相成分であるコランダム粒子の靶性值への寄与は小 さかったことが分かる。

以上のことからシリカーアルミナセラミックスの機械 的性質に及ぼす化学組成の影響は，ガラス相の存在する 組成領域とガラス相の存在しない組成領域により異なっ

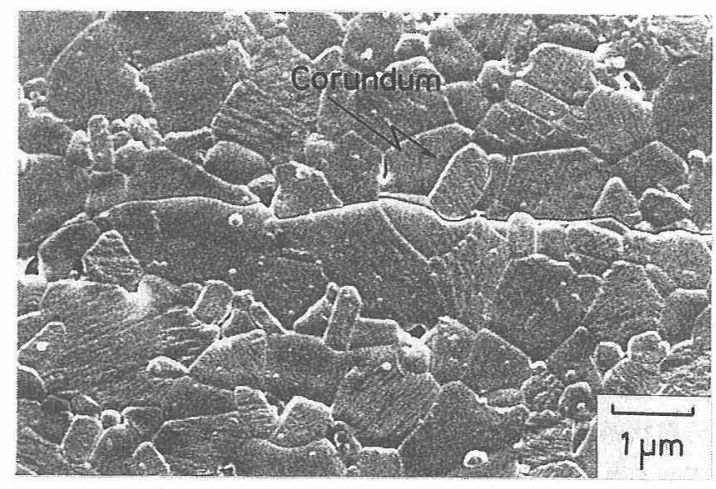

Fig. 10. A scanning electron micrograph of crack path in $78 \mathrm{~A}$ specimen.

た傾向を示すことが分かった．ガラス相の存在する組成 では，高温で応力緩和とクラック先端の鈍化により抗折 強度及び破壊䩲性値は高くなる傾向を示す。それに対し てガラス相の存在しない組成では, 抗折強度及び破壊靫 性值はいずれも温度の上昇とともに低下することが分 かった。また，このように粒界にガラス相が存在する組 成領域でガラス相の粘性が高温で急激に低下しないよう に制御し, 存在するガラス相の量を調整することにより 高温まで機械的性質の低下しないムライトセラミックス が得られることが分かった。

\section{4. まとめ}

噴霧熱分解法により作製したシリカーアルミナセラ ミックスの機械的性質に及ぼす組成の影響について検討 し，次のような結果を得た。

（1）シリカーアルミナセラミックスの機械的性質は, 粒界に存在するガラス相の有無により大きく異なりガラ ス相の存在しないムライト単一組成, コランダム共存組 成では, いずれも抗折強度, 破壊靯性值は温度とともに 低下する傾向を示した。

（2）ガラス相の存在する組成領域での抗折強度, 破 壊鞀性值は, いずれの組成でも室温より高温で高く, ガ ラス相の増加とともに一定の組成範囲で強度は増大し, $68 \mathrm{~A}$ で $1300^{\circ} \mathrm{C}$ の抗折強度は室温の約 1.6 倍の 550 $\mathrm{MPa}$ ，破壊鞁性值は $4.70 \mathrm{MN} / \mathrm{m}^{3 / 2}$ であった。 
（３） ガラス相の存在するシリカーアルミナセラミッ クスの高温強度は, ガラス相の化学組成により最大強度 を示すピーク温度が異なることが分かった。

（4）高温での破壊は，ガラス相の量により異なり， ガラス相が部分的に連続する組成では, $1300^{\circ} \mathrm{C}$ 付近で すでに塑性変形を伴いながら破壊することが分かった。

以上のように, シリカーアルミナセラミックスの機械 的性質は, 化学組成に起因する微構造, 特に粒界相によ り変化し, 高温では粒界にわずかにガラス相が存在する 組成を選ぶことにより, 非常に高い機械的性質を示す七 ラミックスが得られることが分かった。

謝 辞 本研究の強度測定においては, 名古屋工業技術試 験所・主任研究官伊藤 勝氏, 日本セメント（株）中央研究所・ 浅海順治氏の御協力を得た。ここに感謝の意を表します。

\section{文献}

1) W.D. Kingery, H.K. Bowen and D.R. Uhlmann, "Introduction to Ceramics", 2 nd ed., John Wiley \& Sons, Inc., New York (1975) pp. 304-07.

2) P.A. Lessing, R.S. Gordon and K. S. Mazdiyasni, J. Am. Ceram. Soc., 58, 149 (1975).

3) P.C. Dokko, J. A. Pask and K. S. Mazdiyasni, J. Am. Ceram. Soc., 60, 150-55 (1977).

4) Tai-il Mah and K. S. Mazdiyasni, J. Am. Ceram. Soc.,
66, 699-703 (1983).

5) S. Kanzaki, H. Tabata, T. Kumazawa and S. Ohta, J. Am. Ceram. Soc., 68, C 6-7 (1985).

6) S. Kanzaki, T. Kumazawa, J. Asaumi, O. Abe and H. Tabata, 窯協, 93, 407-08 (1985).

7) 熊沢 猛, 神崎修三, 浅海順治, 阿部修実, 田端英世, 窯協, 94, 485-90 (1986).

8) W.F. Brown and J. E. Srawley, ASTM No. 410 (1967).

9) A.A. Griffith, Phil. Trans. Roy. Soc., A 221, 163 (1920).

10) N. Soga and O. L. Anderson, J. Am. Ceram. Soc., 49, 355-59 (1966).

11）熊沢 猛, 神崎修三, 坂口 修, 田端英世, 未発表.

12) F.F. Lange, J. Am. Ceram. Soc., 57, 84-87 (1974).

13) R. W. Davidge and G. Tappin, Proc. Brit. Ceram. Soc., 15, 47-60 (1970).

14）阿波利夫, “新素材シリーズ ムライト”, 宗宮重行編, 内田老鶴圃 (1986).

15) C. R. Cheeseman and G. W. Groves, J. Mater. Sci., 20, 2614-22 (1985).

16) G. W. Morey, “The Properties of Glass", 2 nd ed., Reinhold Publishing Corporation (1954) pp. 132-65.

17) D. P. H. Hasselman and R. M. Fulrath, J. Am. Ceram. Soc., 49, 68 (1966).

18) N. Shinkai, R.C. Bradt and G. E. Rindone, J. NonCryst. Solid, 49, 497 (1982).

19) A. G. Evans and T. G. Langdon, " Progress in Materials Science, Vol. 21 ”, Plenum Press (1976) p. 275.

20) H. Ruf and G. G. Evans, J. Am. Ceram. Soc., 66, 328-32 (1983). 